\title{
Martyrdom, Suffering and Death; Witnessing to The Crucified Christ: A Study of Ignatius of Antioch
}

\author{
Ugwoegbu, Edmund Ugochukwu \\ Merrimack College North Andover Massachusetts, United States \\ Department of Religion and Theological Studies. \\ ugwoegbue@merrimack.edu ugwoegbu@bc.exu \\ DOI: 10.29322/IJSRP.11.12.2021.p12020 \\ http://dx.doi.org/10.29322/IJSRP.11.12.2021.p12020
}

\begin{abstract}
This study focused on Ignatius of Antioch and his witness to the crucified Christ through martyrdom, suffering and death. In Christianity, a martyr is a person considered to have died for his faith and stories of the early years of the church depict that martyrdom often occur via death by stoning, crucifixion or other forms of torture and capital punishment. Ignatius of Antioch is so captivated by the thought of becoming a martyr that he reflects witnessing to Christ through martyrdom in his seven letters and journey to Rome, where he pleaded with Romans not to impede his golden opportunity to be with God through martyrdom (Rom $6: 3$ ). He further posited the significance of suffering, persecution and death together with the practice of martyrdom as a prerequisite in the life of the church today and without which understanding the life of the cross becomes difficult. Finally, it was discovered via Ignatius letters that martyrdom is simply the imitation of Christ and also a means of attaining God because as Christians, we still celebrate Christ in the Eucharistic sacrifice which is a commemoration of the death and resurrection of Christ. The blood of the martyrs is in unity with the blood of Jesus Christ and their blood is the seed, therefore we celebrate martyrdom at the liturgy every day at the holy mass.
\end{abstract}

Index Terms- Martyrdom, Suffering, Cross, Witnessing, Christian.

\section{INTRODUCTION}

$\mathrm{M}$ artyrdom is part and parcel of the Christian experience and the best attitude to develop toward this is openness, knowing fully well that closeness to God and obedience to him is interwoven with the cross. In suffering and persecution, the consequent effect is death, just like the death of Jesus and all those who have modeled their lives on him.

The Sufferings, persecutions and deaths of the martyrs are prerequisites in the life of the Church today, without which understanding the life of the cross becomes difficult. This paper, using key examples from Ignatius of Antioch, reminds Christians that martyrdom is discipleship, imitation of Christ and a means of attaining God.

\section{The Old Testament examples of Martyrdom.}

${ }^{1}$ Candida R. Moss, Ancient Christian Martyrdom: Diverse

Practices, Theologies, and Traditions (London New Haven: Yale University Press, 2012), 38.
A brief trail of the history of persecution takes us back to the Old Testament era when certain Jewish figures were persecuted for their faith in God. The book of Daniel records his persecutions in the hands of his political opponents who convinced the King to institute an edict impeding people to pray to other gods for thirty days. Daniel continues his prayers and is captured and thrown into the Lion's den. King Darius could not do otherwise, and he loves Daniel so much, but cannot help in this situation for the sake of the law. (Dan. 6.7). In the same book, earlier in chapter 3:1-30, Shadrach, Meshach and Abednego were captured and thrown into the fiery furnace to die a shameful death before the King, Nebuchadnezzar, and his people in order to rupture their belief in God. In both cases, the persecutions were extreme but at the end, they were vindicated. These court tales captured the imagination of early Christians who identified with the morally righteous protagonists unfairly betrayed to their deaths by political

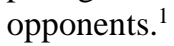

Among the first acts of Martyrdom which were road maps leading to the Christians embrace of martyrdom are the trials of Eleazar and the seven brothers killed before their mother for not obeying the king as against their belief in God. Eleazar at his old age refuses to eat pork which was used for sacrifices to the gods on the birthday of the king. The king and his cohorts chastise him in order to let go of his beliefs and embrace theirs, but Eleazar refuses to adhere to their wish (2maccabees 6:18-31). As a result of this refusal, Eleazar was tortured and finally put to death. The same fate met the mother and her seven sons, as one after the other, they were killed as their mother watches and encourages her children not to give up the faith. (2macc. 7:1-42). The deaths of the "Maccabean martyrs" have served as a perpetual crux in scholarly accounts of the history of martyrdom. ${ }^{2}$ As a matter of fact, many scholars dub the mother with her seven sons and elderly Eleazar as the first martyrs. ${ }^{3}$ In the writings of C. Moss, she notes further that W.H.C. Frend's classic history of Martyrdom starts with a chapter on the Maccabean martyrs, then proceeds to Jesus's time and the early church. Jan Willem Van Henten's study of early martyrdom describes the Maccabean martyrs as the saviors of the Jewish people. ${ }^{4}$ The personalities and contributions of these brothers and their mother, together with Eleazar, are at the foundations of the history of martyrdom and were models for the

\footnotetext{
${ }^{2}$ Candida Moss, Ancient Christian Martyrdom, 39.

${ }^{3}$ Ibid, 40.

${ }^{4}$ Ibid.
} 
early Christians. Their suffering and death still make much meaning to the Christians of today who still reflect on imports of their martyrdom.

\section{THE EARLY CHURCH AND JESUS'S EXAMPLE.}

Jesus' death on the cross led Christians of the early church to hold tenaciously to their belief in Jesus Christ. The early Christians saw themselves as living in the example set for them by the crucified Jesus Christ of Nazareth. For this example of dying on the cross, so many early Christian martyrs surrendered to death in the face of persecution because of their certainty in Christ's gift of himself unto death and in his resurrection from the dead. Paul, addressing his followers in Thessalonica, makes it clear to them; "it behooved the Christ to suffer (Acts 17:3)" and that; "Jesus's blood 'poured out for many' (MK. 14:24, Mt. 26:28= Is.53:12) and for His Name the Christians would be shed also (Mk. 10:30)." In his death, humanity is redeemed. Jesus's suffering, death and resurrection becomes a yardstick for his followers to commit themselves to his teachings and a longing for his kind of death in order to witness to him. Jesus' resurrection is a testimony of eternal life for the Christians that they begin to appreciate more, Christ's gift of himself. This is rooted in his suffering, death and resurrection as an example for Christians who hope in the resurrection and the life of the world to come. Beginning from the Apostles to the Apostolic fathers, from the Apostolic fathers to the Fathers of the Church, the link continues till today. Some references to help us understand the example of Jesus are the Passion narratives of John 19:1-20, Mark 14:1-15:47, Mathew 26 and 27, Luke 23, and the different resurrection accounts of Mathew 28, Luke 24, John 20:1-21:1-24.

\section{PERSECUTION AND SUFFERING IN THE EARLY CHURCH.}

The early Christians see themselves as following in the footsteps of the Master Jesus Christ and this is the key difference between them and the Jews. They were Jews, though their faith in Jesus Christ distinguished them. ${ }^{7}$ The epistles of Paul present us with so many happenstances of persecutions, sufferings and trials of faith at different levels in order to deal with the Christians. In his writings: "it was obvious that persecution was the lot of the Christian (Rom. 8:36; 1Thess. 3:3-4; Tim. 3:12),"8 though his personal sufferings as an apostle occupy the center stage of his writings.

The early Christians suffered severe persecutions at one time or another, beginning from the time of Christ up until the edict of Milan in A.D.313. ${ }^{9}$ The Roman Empire tolerated the Christians

\footnotetext{
${ }^{5}$ W. H.C. Frend, Martyrdom and Persecusion in the Early Church: A Study of a Conflict from the Maccabees to Donatus (Oxford: Alden Press, 1965), 81

${ }^{6}$ Ibid.

${ }^{7}$ Henry Chadwick, The Early Church, (New York: Dorset Press, 1986), 9.

${ }^{8}$ William C. Weinrich, Spirit and Martyrdom: A Study of the Work of the Holy Spirit in Contexts of Persecution and Martyrdom in the New Testament and Early Christian Literature, (Washington D.C.: University Press of America, 1981), 43.
}

and their beliefs for a long time, viewing them almost in the same mirror with the Jews. Christians came into conflict with the State in the first instance by accident, not on any fundamental point of principle. ${ }^{10}$ The burning of Rome in A.D.64 is a determining factor for the change in attitude of the Romans who begin to see the Christians as the black sheep due to Nero's accusing the Christians as those responsible for the fire. With regards to this fire, Tacitus (A.D. ca. 55-177), the Roman Historian notes that:

To suppress (the rumor that the fires that destroyed Rome had been deliberately set). Nero fabricated scapegoats-and punished with every refinement the notoriously depraved Christians (as they were popularly called). Their originator (one "Chrestos,") had been executed in Tiberius' reign by the governor of Judaea, Pontius Pilate. But in spite of this temporary setback the deadly superstition had broken out afresh, not only in Judaea (where the mischief had started) but even in Rome. All degraded and shameful practices and flourish in the capital. ${ }^{11}$

The emperor Nero was suspected of arson in his empire and was not as popular as the other emperors before him. Nero fabricates scapegoats and punishes Christians for this act. The reasons for assigning this fire to Christians is not clear; Christians were scapegoated and blamed since he doesn't really know them. They were seen as people who practice incest and cannibalism because of their belief in the Eucharist. This persecution was in Rome and the key reason is that somebody had to bear the blame of the fire, nevertheless, it was a precedent that magistrates had condemned Christians to death because they were Christians and on no other charge. ${ }^{12}$

Another persecution of interest in the early church before the Ignatius arrest is by the Emperor Domitian (81-96), who named himself "God and Master,"13 and wouldn't tolerate anybody not giving him such honor. He introduces the customary oath by the genius of the Emperor and mandated all to be part of it. Those who could not be part of this were described as atheists and punished with death for not paying allegiance to the Emperor as "God and Master."

There are other persecutions before the edict of Milan in 313 by Constantine. In 250, Decius comes in with reforms aimed at the restoration of the traditional Roman discipline. ${ }^{14}$ His target was to unite all the forces of the empire, and to promote sacrifices to the gods of the empire. His edict is not really known but Christians were persecuted sometime in late 249 , and in $250^{15}$, the higher clergies and some other Christians were seized and executed (Pope Fabian and Bishop Babylas in Antioch). Diocletian and his adopted son Galerius also persecuted the church 303-311 before the edict of Milan in 313.

Christians were persecuted primarily because of their faith in Jesus Christ and refusal to renounce the faith. The early Christians

\footnotetext{
${ }^{9}$ Ivo Lesbaupin, Blessed are the Persecuted: Christian Life in the Roman Empire, A.D. 64-313 (New York: Orbis Books, 1974), 1.

${ }^{10}$ H. Chadwick, The Early Church, 25.

${ }^{11}$ Ivo Lebaupin, Blessed are the Persecuted, 2.

${ }^{12}$ H.Chadwick, The Early Church, 26.

13 Ibid.

${ }^{14}$ Frend, Martyrdom and Persecution in the Early Church, 405.

${ }^{15}$ Frend, Martyrdom and Persecution in the Early Church, 406.
} 
were firm in the profession of their faith, holding unto their baptismal promises and not letting anybody pull them away from their belief. They believed in Jesus, born of the Virgin Mary, suffered death on Cross and was buried. And most importantly, after three days, he rises from the dead. This was the faith of the early Christians and they were persecuted and many died for this belief.

Another trace of persecution in the early Church is during Trajan's reign as Emperor which I will describe in the letters between him and Pliny the Younger. Pliny the younger, the governor of the city of Bithynia c. $112^{16}$, writes Trajan explaining the real situation of things with regard to the Christians and to know the best way to handle them. In his explanations, he notes that, he finds them innocent of any crime except that they gather on a certain day before sun-rise and with two choirs sing hymns in honor of Christ, whom they look upon as God. ${ }^{17}$ The report continues as he tells the emperor that Christians take an oath that restricts them from getting into crimes like adultery and rubbery. They agree to be faithful to their faith which they hold as the truth. ${ }^{18}$ The Christians were not involved in any superstitious beliefs and practices as regards their faith and Pliny couldn't find any reasonable evidence against them in order to keep pushing for the infringement on their rights. He narrates to the emperor that he has suspended all charges against the Christians but is presenting the situation before him since some have been implicated for being part of the group, so that he can take his decisions.

In Trajan's reply to Pliny the Younger, he commends Pliny: "You have adopted the proper course, my dear Secundus,"19 and makes it clear to Pliny that nothing can be laid down as a form of procedure in relation to the case at hand. He doesn't need to seek Christians out; rather, anyone who is caught and refuses to renounce his/her stand, let the person be denounced and punished for that and any who renounces Christianity and worships the gods should be pardoned completely. He insisted the papers must be signed and unsigned papers should not be accepted as it is "unworthy of our time," 20 says Trajan.

\section{IGNATIUS OF ANTIOCH AND HIS JOURNEY TO ROME, AND HIS LETTERS. C. 107-110.}

Ignatius was the Bishop of Antioch sometime toward the end of the first century (Eusebius, Hist. eccl.3.21-22) and died in the early part of the second century, likely during the reign of Trajan. ${ }^{21}$ He was a holy man who fought for the unity of the church, against heresy and longed for martyrdom as evidenced in his epistles which he wrote on his way to Rome after his arrest. The traditional understanding on Ignatius of Antioch is that he was seized during a persecution in Antioch and sent to Rome to suffer in severe manner. ${ }^{22}$ This insight is necessary as it alludes to the joy he had

${ }^{16}$ J. Stevenson ed., The New Eusebius: Documents illustrating the history of the Church to AD 337, ( Cambridge: University Press, 1987), 18

17 Ibid.

18 Ibid.

${ }^{19}$ J. Stevensonn ed., New Eusebius, 20.

${ }^{20}$ Ibid., 21

${ }^{21}$ Candida Moss, Ancient Christian Martyrdom, 52. at Troas on getting the news of the "Peace" in the Church of Antioch (Phd. 10.1), he understands it as an end to the persecution that was on in Antioch.

Meanwhile, Ignatius of Antioch, firmly aware of the sufferings of the followers of Christ in this period of the church's growth, sees martyrdom as a perfect means of fulfillment in his journey of faith. The strength, energy and courage of the past heroes of faith influence him to have a severe urge for martyrdom. For Ignatius, he can only attain true discipleship by dying for the sake of his faith through martyrdom in order that his dream may come true.

Ignatius of Antioch writes seven beautiful epistles to the Churches of Asia minor and the Roman community on his way to Rome for his martyrdom. In these seven genuine letters written to the churches in Asia Minor, circa 107-108, and to the Roman community itself, he offers a robust theology of martyrdom for the primitive church. ${ }^{23}$ Apart from Paul, Ignatius of Antioch is the first Christian martyr who left clues to his state of mind as he embarked on this journey that leads him to the amphitheater in Rome from Antioch, to the cities of Asia Minor, to Troas Via Egnatia and finally, to Rome ${ }^{24}$ for his martyrdom.

The letters of Ignatius of Antioch are seven in number, including the letter to the Romans where he pleads with them not to impede his golden opportunity to be with God through martyrdom. These seven letters to the Ephesians, Magnesians, Trallians, Romans, Philadelphians, Smyrneans, and to Polycarp are commonly called the middle recension. ${ }^{25}$ This is because there are other recensions, the long and short recensions. The long and short recensions are believed to be additions of some other scholars in the fourth century, most especially the long recension. Among these recensions, the authentic and genuine one is the middle recension that contains only the seven letters named above. These letters are manifestations of Ignatius' zeal and love for the Church. He writes them as he moves during this journey to Rome, and it is important to note that though a condemned man, with soldiers guarding him, he is able to compose these. In the seven letters, the letter to Polycarp and the letter to the Romans are completely different from the other five letters. The letter to Polycarp is a pastoral exhortation from one local ordinary to the other, while the letter to the Romans unfolds his plea to the Romans that they allow him to actualize his being through martyrdom. It is easily noticed in the letter to the Romans that Ignatius does not really have a personal link to the Church in Rome but in the other letters, you see a pastor addressing a people he has a link with.

These letters of Ignatius of Antioch unfold three major concerns which are of key interest to him. He longs for unity in the local churches that he writes to, since as a Bishop, the unity of the church is of paramount interest to him. The second reason is to build a well cemented faith on the part of the Christians because

\footnotetext{
${ }^{22}$ William R. Schoedel, Ignatius of Antioch: A Commentary on the Letters of Ignatius of Antioch (Philadelphia: Fortress Press, 1985), 10. All quotes and references from Ignatius of Antioch's letters is from W. R. Schoedel.

${ }^{23}$ Frend, Martyrdom and Persecution in the early church, 196.

${ }^{24}$ Ibid.

${ }^{25}$ Candida Moss, Martyrdom in the Early Church, 53.
} 
of the rise of heretics and heresy during this period. The key heresy during this time, which is evident in his letters, is Docetism. It maintains that the incarnation of Christ, his death and resurrection, did not really take place. Primarily, it is a problem of those who question the divinity of Christ and finally, Ignatius is eager to recruit the help of his correspondents in the successful completion of his own vocation which is nothing less than a call to martyrdom. ${ }^{26}$ These points are at the heart of Ignatius' letters and so many scholars have criticized Ignatius because of his attachment and love for martyrdom.

During this journey to Rome, he writes to the Romans making it explicitly clear to them that they allow him to benefit from the wild beasts prepared for him. He writes:

I am fighting wild beasts from Syria to Rome, through land and sea, by night and day, bound to ten leopards-which is a company of soldiers-who when well treated become worse. By their mistreatment I become more of a disciple, but "not for that reason am I justified." 2/ May I benefit from the wild beasts prepared for me, and I pray that they will be found prompt with me, whom I shall even entice to devour me promptly-not as with some whom they were too timid to touch; and should they not consent voluntarily, I shall force them. 3/ Indulge me; I know what is to my advantage; now I begin to be a disciple and invisible envy me. Fire and cross, and packs of wild beasts, the wrenching of bones, the mangling of limbs, the grinding of the whole body, evil punishments of the devil-let these come upon me, only that I may attain Jesus Christ. ${ }^{27}$ (Rm.5)

The tone of this paragraph in the letter to the Romans is challenging; this is a man in chains and guarded by ten soldiers and he talks about "fighting wild beasts," and proclaims himself a 'War Lord.' Ignatius sees himself as a victor, a conqueror who though still on the way to engage in a war has already won the war, even before fighting it. This is to show the joy with which he receives his present suffering and the anticipation to grab his gift of martyrdom. Grant calls this style of writing here a "regal imperial style," 28 and such a style of writing is also typical of Paul, who boasts of his predicaments in the hands of his persecutors (2Cor. 11:16-29). W. Schoedel explains that: the expression "through land and sea" in this paragraph of Ignatius' letter plays a natural role in the context of imperial claims to extraordinary achievements and the phrase "by night and day" is calling to mind the theme of sleepless toil in the writings of Paul. ${ }^{29}$ This is a means of telling his audience that he passes through all these in order that his dream may come true.

Commenting on the historical perspective of this key passage, Schoedel explains more that the troop guarding Ignatius represented perhaps a conturbernium (later also called manipulus), a division of the century which ideally consisted of ten soldiers. Invariably therefore, ten soldiers are too big for just one condemned man. It is implicitly correct to say that there were many other prisoners who travelled with Ignatius though he never

${ }^{26}$ Micheal A. G. Haykin, "Come to the Father: Ignatius of Antioch and his calling to be a martyr," Themelios, 32, no. 3 (2007), 32.

${ }^{27}$ William R. Schoedel, Ignatius of Antioch, 178

${ }^{28}$ Ibid.

${ }^{29}$ Ibid

This publication is licensed under Creative Commons Attribution CC BY

http://dx.doi.org/10.29322/IJSRP.11.12.2021.p12020 mentions them at all, he may not have deemed it necessary to talk about the other captors.

For Ignatius, one thing is most important as he makes this journey and that is to conquer. In order to achieve this, he turns his journey to the capital as a prisoner into a victorious campaign against opposing forces whose most immediate embodiment are the representatives of Rome - the ten leopards who hold him bound. ${ }^{30}$ For him, victory awaits him at the amphitheater where he will be torn into pieces by the lions. The fulfillment of his life depends on this, and he wouldn't want anybody from blocking this opportunity. He longs to be a disciple of Jesus, and this can only be achieved through his death at the theatre which will lead to his justification. In this context, justification for Ignatius is apparently nothing other than becoming a disciple (Tr. 5.2) and gaining perfection (cf. Phd. 8.2.) through martyrdom. ${ }^{31}$ Therefore, this justification is still futuristic.

In the final part of this paragraph, Ignatius expresses the hope that he may benefit from the wild beasts and longs for them to tear him into pieces without wasting time. In some cases, the wild animals might be reluctant to attack its prey, maybe because of the enormous ovation inside the amphitheater. So many saints are famous today because they seduce the animals into feasting on them in such situations. This is the dream of Ignatius, if they are not fast to do their job.

The readiness to do this is fascinating though at some points he sees himself as unworthy of this goal. Ignatius was ready to do anything in order to attain God. Instances of fire and severe tortures are found in the history of early Christians, believers were hung on crosses, some crucified and some hung and lighted like candles at night, especially during the reign of Nero. Being aware of these horrors, he still wishes to be part of it and is joyous that it is coming his way. The greatest obstacle he feared was the Roman Christians who might decide to get him out of this dream. Having known him as a man of God and his contributions to the Church in Antioch and the churches of Asia Minor, they wouldn't want him to die so soon. This fear is noticeable all through his letters to the Roman Christians as he pleads to be allowed to imitate his God (Rom. 6. 3). This happened somewhere around AD 107 and AD $110^{32}$ though the actual date is still disputable.

\section{INTERPRETING IGNATIUS AND SOME SCHOLARLY CRITIQUES OF HIS POSITION.}

In reading the entire letter to the Romans, one begins to wonder why Ignatius of Antioch is so captivated by the thought of becoming a martyr. Sometimes, certain people begin to ask if he is actually psychologically sound for reasoning along these lines. Article five of the above paragraph brings out the arrogance of Ignatius in longing for martyrdom. Is he really sane for this excessive longing for martyrdom? W.H.C Frend describes Ignatius of Antioch's letters as displaying a state of exaltation

\footnotetext{
${ }^{30}$ Schoedel, Ignatius of Antioch, 179.

31 Ibid.

${ }^{32}$ Micheal A. G. Haykins, "Come to the Father," 29. Schoedel suggests Ignatius martyrdom might conceivable be placed as late as AD 135 or a date before the death of the Emperor Trajan in AD 117.
} 
bordering on mania. ${ }^{33}$ It is not abnormal for writers to feel this way when engaging the works of Ignatius of Antioch. The comprehension of the letter to the Romans is always problematic because it portrays him as egoistic and boastful in relation to his quest for martyrdom. G.E.M. de Ste. Croix states bluntly that, Ignatius has 'a pathological yearning' for death, the sure sign of 'an abnormal mentality.' ${ }^{34}$ I am not surprised at these positions, understanding Ignatius is always difficult especially, in interpreting him with only human reasoning, but Ignatius himself knows exactly that Christian belief in God demands-- a passionate engagement of the entire person, even to the point of physical death.

In Kevin Vahoozer's view, martyrdom for Ignatius is a powerful form of a truth disclosive action, namely, the truth about Christ and about himself as a Christian. ${ }^{35}$ In his letters, you also see a man who knows and is convinced of what he wants and makes an effort to make it his own. Some other scholars maintain that Ignatius was influenced by the gnostic myth of the redeemed redeemer, while Wetter and Bartsch also maintain that Ignatius reflects conceptions of the mystery cults. ${ }^{36}$ It is very clear as theologians testify that the texts of Ignatius can very well be interpreted without reference to pagan cults. The structure of his letters are very biblical, being especially influenced by $\mathrm{John}^{37}$ and Paul.

One of the key things to recognize and to keep in mind in the letters of Ignatius of Antioch is that Ignatius reflects on his own coming martyrdom. ${ }^{38} \mathrm{He}$ is not giving a systematic or dogmatic theology of martyrdom; rather what he says, he says of himself as one who is going into death because he is a Christian. ${ }^{39}$ As a Christian, his will is to die for the sake of Jesus Christ so that his claim to be a Christian will be seen to be more than mere words and will be crowned by deeds. This is viewed in his letter to the Roman Christians where he urges them to "keep your mouths sealed," if they are able to do this for him, they will enable him become "a word of God." (Rm.1.2-2.1) ${ }^{40}$ This is to say that, if the Romans keep silent and do not push for his freedom, then his martyrdom will prove the sincerity and steadfastness of his faith to the world.

In showing his longing to follow Christ, I will describe further, what he means by discipleship and imitation of Christ.

\section{MARTYRDOM AS DISCIPLESHIP}

Ignatius sees his Martyrdom as a means of true discipleship. In Romans he tries to explain his calling to discipleship through martyrdom thus: "instead, entice the wild beasts that they may become my tomb and leave behind no part of my body that when

\footnotetext{
${ }^{33}$ Frend, Martyrdom and Persecution in the Early Church, 197.

${ }^{34}$ M. Haykin, "Come to the Father," 28.

${ }^{35}$ Ibid.

${ }^{36}$ William C. Weirich, Spirit and Martyrdom, A study of the

Work of the Holy Spirit in Contexts of Persecution and

Martyrdom in the New Testament and Early Christian Literature

(Washington: University Press of America, 1981), 111

37 Ibid, 112

${ }^{38}$ Ibid.
}

I fall asleep, I may burden no one. Then I shall truly be a disciple of Jesus Christ when the world will not even see my body" and then, "I may be found a sacrifice of God" (Rm. 4. 2). Ignatius seemingly enjoys this situation of the disappearance of his body, not just because he wouldn't be a burden to anyone again but because it will mark the completeness of his transformation and the attainment of true discipleship. ${ }^{41}$ Due to his quest, Schoedel notes that he overdramatizes the event. The act of enticing the beasts as he requests the Christians, is that they play the role of those who from the sidelines stirred reluctant animals to attack (Eusebius Hist. eccl. 8. 7. 2) ) $^{42}$

He expresses his inferiority to Peter and Paul who were apostles, and he sees them on a different level from the beginning (Mag. 6. 1). Both of them are seen as engraving their characters in the lives of the different churches where they worked. Ignatius believes that it is only through martyrdom that he can become like Peter and Paul who command much respect and obedience in the Christian community. Ignatius, though a disciple of John, is influenced by the writings of Paul, and this provides him with the vocabulary and the systematization of his own letters. For him, Paul was someone worthy of being listened to, not only because he was someone worthy of being listened to, not only because he was one of the apostles but because he was attested as a disciple who had in fact attained God. ${ }^{43}$ His knowledge of Paul is indisputable, and this helps him to give up everything and desires nothing in return in order to be as they were.

True discipleship for Ignatius therefore merges with death. As a witness to the death and resurrection of Christ, only at this level can true discipleship be found. The bounding together of disciple and Master is the truth of martyrdom. Ignatius' life is tied to the cross of Christ and is summed up by the words $\dot{\varepsilon} v X \rho \imath \sigma \tau \tilde{\omega}$, as seen in his saying that his soul is devoted to the Cross, which is an offence to unbelievers, but to us salvation and eternal life (Ephes., 18.1). ${ }^{44}$ It is always better to die for Christ Jesus than to be a worldly king. (Rm 6.1.) True discipleship anchors on true devotion of the Christian to the Master, Jesus Christ.

\section{MARTYRDOM AS IMITATION OF CHRIST.}

God is the author of martyrdom in Ignatius's appreciation of martyrdom and his confidence that God will appreciate the choice he has made. This is clear in the letter to the Romans where he describes himself as "God's wheat and the purest bread for Christ."(Rm. 4. 1) ${ }^{45}$ God appreciates those who die for the sake of their faith in him. Ignatius believes that he speaks God's word and is not voicing humans' thoughts (Rm. 8. 3). Are we sure that Ignatius' Martyrdom will please God?

\footnotetext{
${ }^{39}$ William C.Weinrich, Spirit and Martyrdom, 115.

${ }^{40}$ Schoedel, Ignatius of Antioch, 170.

${ }^{41}$ Ibid.

${ }^{42}$ Ibid. 176.

${ }^{43}$ Robert F. Stoops, JR, "If I Suffer...Epistolary Authority in Ignatius of Antioch, Hard Theological Review," 80, no. 2, (1987), 177.

${ }^{44}$ W. H. C. Frend, Martyrdom and Persecution in the Early Church, 199.

${ }^{45}$ Shoedel, Ignatius of Antioch, 175
} 
Imitation of Christ is being with Jesus Christ unto death. He pleads with the Romans to allow him to imitate the passion of Jesus Christ (Rm. 6.3). If Jesus Christ died for the sake of humanity, treated in an awful way, and he never revolted, therefore, the death of a Christian through martyrdom as imitation of the passion of the Lord, is worth going for. In imitating Christ, Ignatius renounces the world and gives himself completely to God. Once more, better to die in God than to be king of the world.

A pertinent question that comes up here is; if Christ's death on the Cross conquered sin, why is martyrdom necessary? It is important to note that Christ has offered one single sacrifice and salvation has been offered to all, but we have to work out this salvation, consequently, through human effort. The gate is open but we need to model our lives like unto Christ. Ignatius makes it clear that "it is better for me to die to Jesus Christ than to rule the ends of the earth. I seek him who died on our behalf; I want him who arose for our sake (Rm. 6.1)." This is a complete denial of the things of the world and an embrace of heavenly things.

Another point here is Ignatius' understanding of eternal life, which shows that life in Jesus is eternal. He pleads: "Indulge me brothers, do not prevent me from living, do not want my death, do not give to the world one who wants to be God's (Eph. 6.2)." This shows that for him, to die, is to live eternally with God and to live in this world, is to want his death. This gives meaning to the Theology of martyrdom which Ignatius longs for. For him, one cannot serve two masters at a time, you cannot profess Jesus Christ and desire the world at the same time (Rm. 7.1).

In martyrdom, we notice clearly that the world of the Roman Empire was not on the best of terms with the Christians and their God. ${ }^{46}$ Imitation of Christ is the guiding concept in Ignatius' understanding of his martyrdom. ${ }^{47}$ In imitating Christ, he crucifies all earthly longing, as he notes in Romans 7.8, "Earthly longings have been crucified and in me there is no spark of desire for mundane things, but only a murmur of living water that whispers within me, Come to the Father." 48 Imitation of Christ is to die for the sake of Christ, dying to the world, but living in and sharing in Christ's resurrection.

He sees martyrdom as a sacrifice, a following of the examples of the Hebrew prophets. They lived according to Jesus Christ's precepts, suffered persecution as inspired by his grace to convince the disobedient that there is God who manifested himself through Jesus Christ his son $^{49}$ (Magnes., 8. 2). Martyrdom in being a sacrifice is then part and parcel of the liturgy. The Eucharist is the summit of our Christian worship. Both martyrdom and the performance of the Eucharist function as imitations of the passion of Jesus and provide access to this communion with God. ${ }^{50}$ Ignatius's death as a sacrifice, just like the Eucharist, serves as a means for the revitalization of the church's unity and he describes the Eucharist as the "medicine of immortality." 51 Martyrdom serves a series of purposes for Ignatius of Antioch. Martyrdom allows him to position himself just like Paul to establish his own authority in the Church. It gives him a voice in the history and life of the church. A critical look at Ignatius' works shows that the

\footnotetext{
${ }^{46}$ M. Haykin, "Come to the Father," 35.

${ }^{47}$ William Weinrich, Spirit and Martyrdom, 111.

${ }^{48}$ Schoedel, Ignatius of Antioch, 181.

${ }^{49}$ Frend, Martyrdom and Persecution in the Early Church, 199.

${ }^{50}$ C. Moss, Ancient Christian Martyrdom, 55.
}

This publication is licensed under Creative Commons Attribution CC BY

http://dx.doi.org/10.29322/IJSRP.11.12.2021.p12020 linguistic function of martyrdom, suffering and witness is tied to the ideas of discipleship, sacrifice and imitation of Christ. ${ }^{52}$ As Christians today, how can we respond to Ignatius' vision and longing for Martyrdom?

\section{IGNATIUS ON LOVE AND THE EUCHARIST.}

First of all, Ignatius refers to Christ as "both fleshly and spiritual" (Eph. 7.2); this is a belief in the incarnation of Christ Jesus who is spiritual, taking the form of humans in order to sanctify and redeem the world. The incarnation is a gift of love, the spiritual being coming into flesh to make way for humans, and in such a context, it is natural for salvation to be conceived of primarily in terms of the transformation of human nature by the resurrection. ${ }^{53}$ In martyrdom, Ignatius simply seeks a God who has first loved him. His view on love centers on the person of Jesus Christ, who becomes man, suffers, dies, buried and finally resurrects from the dead.

In his letters to the Ephesians, one sees a clearer picture of the manifestation of love in his admonitions to the church. Ignatius' greetings in the first paragraph, recognizes the effort of the Ephesians and their love for Jesus Christ, "having received in God, your much loved name (Eph. 1. 1)," and this they possessed through their faith and love in Jesus Christ. Through this love in Jesus Christ, one sees the connection he makes between love and the Eucharist.

In his letters, one sees the connection between his love for God and the celebration of the Eucharist. In his continuous plea to the Romans to be allowed to embrace his martyrdom, he reminds them that "I am the Wheat of God, and I am ground by the teeth of wild beasts that I may be found pure bread" (Rm. 4:1). This is a plea from a heart that is full of divine love. It shows his love and interest in the Eucharistic banquet. In this, Schroeder explains it in a way that Ignatius wishes to become the food of wild beasts and likens himself to grain ground in a mill and made into pure bread. The statement is as such regarded as inspired by Eucharistic meal, thus as making his martyrdom a quasi-Eucharistic event. ${ }^{54}$ Pure bread is in connection to sacrifices or religious meals while grinding is a terminology in baking business. These sayings reflect his attitude and attachment to the Eucharist, a celebration of love. In his writings, he urges the Ephesians to be in unity with their Bishop and calls for total obedience to the Bishop. They have to cling to the Bishop like "strings to cithara; therefore, in your concord and harmonious love, Jesus Christ is sung” (Eph. 4. 1). This unity is celebrated during the Eucharist which he describes as love that is first passible and then impassible, Jesus Christ our Lord (Eph. 7. 1). The Eucharist is to be celebrated under the Bishop and all is expected to be part of it, no deception of self, all should gather within the altar of sacrifice and together their prayer will be more efficient (Eph. 5. 2). In the Eucharist which is the "real presence of Jesus Christ," Jesus Christ is being celebrated by the Christians as they partake in the body and blood of Christ.

\footnotetext{
51 Ibid.

52 lbid., 57.

${ }^{53}$ Schoedel, Ignatius of Antioch, 20.

${ }^{54}$ Schoedel, Ignatius of Antioch, 176.
} 
There are so many other references to love as celebrated in the Eucharist, and this is a celebration of faith and love. For Ignatius, faith and love are at the basis of Christian life, faith as the beginning and love as the end of life (Eph. 14. 1). ${ }^{55}$ Other helpful references are; Relationship between the Cross and the Theological virtues (Eph. 9.1), The Eucharist breaks the power of Satan (Eph. 13.1), Eucharist as medicine of immortality, the antidote of death, but leading to life in Jesus Christ (Eph. 20. 2).

\section{THE REIGN OF CHARITY: HOW CHRISTIANS RESPOND TO MARTYRDOM.}

The Martyrdom of Ignatius of Antioch and the role it plays in the life of the Church today cannot be under estimated. I describe the Christian response and attitude toward martyrdom from the examples of the early Christian martyrs like Ignatius of Antioch as the "The Reign of Charity." The Church from the time of Ignatius of Antioch till today continues to suffer persecution of different kinds. The world is still very hostile to Christians and the gospel which they carry along, a hostility which has given so many Christians the opportunity to embrace the call to martyrdom, dying in order to become imitators of Christ (Eph. 10.1-3). Imitating the death of Christ through renunciations and in the hope of being in eternal life with God at the end of the present life.

At the dawn of the twentieth century, during the pontificate of the Holy Pope John Paul II, he raises the consciousness of the Christian community in his apostolic letter Tertio Millenio Adveniente, where he proclaims "In the twentieth century, the martyrs returned." 56 The Pope sees to the beatification or canonization of not less than thirty martyrs of the $20^{\text {th }}$ century ${ }^{57}$ as noted in the speech of the martyrs of the twentieth century. He talks about those who suffered martyrdom as a result of communism and those who suffered in the hands of the Nazi movement. These accepted no compromise for the sake of their faith in Christ, especially priests and religious killed by the Nazis. From the early church, martyrdom is viewed as a driving force in the life of the church as Tertullian says that, "the blood of Martyrs is the seed bed of Christianity." Christians are still going through persecutions, from the early church to the twentieth century, progressing still in the present century.

In many countries of the world, Christians are still persecuted and martyred for their faith. Christians suffer in the hands of Muslims in countries like Nigeria, where Boko Haram (Western Education is evil), a Jihadist movement that has caused so much terror through the kidnaping of secondary school girls and the bombing of many Christians at worship sites in Nigeria. In Syria, another group, ISIS, is causing the same mayhem to

\footnotetext{
55 Ibid., 76.

56 John Paul II. "Apostolic Letter on Preparation for the Jubilee Year 2000,” Tertio Millenio Advernite (10 November 1994), §37, at The Holy See, www.vatican.va/jubilee

${ }^{57}$ Vincente Carcel Orti, "Teachings of John Paul II on the Martyrs of Our Time," In Tertio Millenio Advernite. Accessed 3 May, 2015. www.vatican.va

${ }^{58}$ Catholic News World, "Breaking News: 21 Coptic Christians killed by Terrorists, Martyrs of the Coptic Church," Posted
}

Christians in their bid for an Islamic State. So many lives have been lost and there is no sign that the persecutions will stop. In Kenya, on the $2^{\text {nd }}$ of April, 2015, about one hundred and fortyseven Christian students were killed by the Somalian militant group al-shabab, after separating them from the Muslim students.

That's not the end, on the $22^{\text {nd }}$ of February, 2015, twentyone Egyptian Coptic Christians were killed by ISIS in Libya. To this, Pope Tawadros II announced the names of the 21 murdered will be inscribed in the Coptic Synaxarium. This is a type of Roman Martyrology for the Coptic Christians and means, that they are canonized. ${ }^{58}$ According to a brother of two of the martyrs Bashir Kamel: "ISIS gave us more than we asked when they didn't edit out the part where they declared their faith and called upon Jesus Christ. ISIS helped us strengthen our faith." ${ }^{59}$ In the midst of these persecutions and martyrdom, Christians are still much more steadfast in their faith. The title of the message from ISIS to the world and Christians in particular read: "A message signed in Blood to the nation of the Cross." 60 Yes, salvation comes through the shedding of his blood, the martyrs are partakers in this divine mystery. One thing I have to clear here is that, suffering and consequent death of these Christians, is a byproduct of their love for Christ. Some of them might have had the opportunity to renounce Christ, but they never did that because of their Faith in Christ.

This is not to support the killing of Christians in anyway, because killing is not good since no human has the right to take away another person's life. It is in no way to encourage Christians to solicit for martyrdom; rather, it is to call our consciousness to the reality of martyrdom and our response to it as Christians. Killing is condemned everywhere in the world, and the killing of Christians is completely wrong but the Christian accepts such persecution and suffering for the sake of Christ. Martyrdom is not only the sign of the greatest love but, it is a super-eminent gift of love. ${ }^{61}$ Suffering and martyrdom become a resultant effect of loving Christ as evidenced in the letters of Ignatius and his theology of martyrdom.

Ignatius does not actually recommend martyrdom for anybody but sees it as his own way of actualizing himself in order to attain God .The example of Ignatius of Antioch helps Christians to work toward the unity of the church. Ignatius's willingness to suffer both in life and in death is crucial to the influence he hopes to exercise on behalf of church unity under the bishops of Asia Minor. ${ }^{62} \mathrm{He}$ encourages Christians to be responsible and obedient to the hierarchy of the church, the Bishops, Presbyters and the Deacons, through his death, the Christians of today appreciates this call more. To bear witness to Christ crucified, the Christian buries himself in the love of Christ even unto death, knowing fully that life comes with death in the Lord, which is to say that, there

February 15, 2015. Accessed May 42015.

http://jceworld.blogspot.com/2015/02/21-coptic-christians-killedby.html.

59 Ibid.

60 Ibid.

${ }^{61}$ Ysabel de Andia, "Martyrdom and Truth: From Ignatius of Antioch to the Monks of Tibhirine." Communio 29, no. 1, (2002), 78 .

${ }^{62}$ Robert F. Stoops, "IF I Suffer, Epistolary Authority in Ignatius of Antioch," 173. 
is no death in God. A portrayal of true discipleship, faith and hope in the resurrection of the dead, in and through Jesus Christ is a perfect show of charity. Ignatius shows this love through his faith at the moment of martyrdom. His condemnation gives him the chance to demonstrate his faith in a clear and public manner. ${ }^{63}$ The church of today still manifests this level of piety which is a reciprocation of Christ's love for the Church.

In conclusion, this paper has examined Ignatius of Antioch's coming death, and his theology on martyrdom that he reflects on in his letters. We have seen beginning from the Old Testament accounts, sequentially to the journey and letters of Ignatius of Antioch, that martyrdom is imitation of Christ, discipleship, and a means of attaining God. As Christians, we still celebrate Christ in the Eucharistic sacrifice which is a commemoration of the death and resurrection of Christ. The blood of the martyrs is in unity with the blood of Jesus Christ and their blood is the seed, therefore we celebrate martyrdom at the liturgy every day. At the holy Mass, Christians are united with Christ and his martyrs in a bond of sacrifice, a bond of love. A commemoration of Christ's passion; his suffering, death and resurrection and a sure hope of the life to come.

\section{REFERENCES}

[1] Andia, Ysabel de. "Martyrdom and Truth: From Ignatius of Antioch to the Monks of Tibhirine."

[2] Communio 29, no. 1, (2002): 62- 88.

[3] Chadwick, Henry. The Early Church, New York: Dorset Press, 1986.

[4] Frend, W. H. C., Martyrdom and Persecution in the early church: A Study of a Conflict from the Maccabees to Donatus, Oxford: Alden Press, 1965.
[5] Haykin, Micheal A. G., "Come to the Father: Ignatius of Antioch and his calling to be a martyr, Themelios, 32, no. 3 (2007): 26-39

[6] Ivo Lesbaupin, Blessed are the Persecuted: Christian Life in the Roman Empire, A.D. 64-313.

[7] Maryknoll, New York: Orbis Books, 1974.

[8] Moss, Candida R., Ancient Christian Martyrdom: Diverse Practices, Theologies, and Traditions.

[9] New Haven, London: Yale University Press, 2012.

[10] Schoedel, William R., Ignatius of Antioch: A Commentary on the Letters of Ignatius of Antioch, Philadelphia: Fortress Press, 1985.

[11] Stevenson J. ed., The New Eusebius: Documents illustrating the history of the Church to AD 337, Cambridge: University Press, 1987.

[12] Stoops, Robert F. JR., "If I Suffer: Epistolary Authority in Ignatius of Antioch," Harvard Theological Review 80, 2 (1987): 161-178.

[13] Weinrich, William C., Spirit and Martyrdom: A Study of the Work of the Holy Spirit in Contexts of Persecution and Martyrdom in the New Testament and Early Christian Literature, Washington D.C.: University Press of America, 1981.

[14] John Paul II, Tertio Millenio Advernite 'On Preparation for the Jubilee Year 2000

[15] http://www.vatican.va/jubilee_2000/pju_en.htm Nov 101994.

[16] Catholic News World, "Breaking News: 21 Coptic Christians killed by Terrorists, Martyrs of the Coptic Church," Posted February 15, 2015 Accessed May 4 2015. In http://jceworld.blogspot.com/2015/02/21-copticchristians-killed-by.html

[17] Orti, Carcel Vincente, "Teachings of John Paul II on the Martyrs of Our Time," In Tertio Millenio Advernite. Accessed 3 May, 2015. www.vatican.va

\section{AUTHORS}

First Author - Ugwoegbu, Edmund.Ugochukwu

Boston College, Chestnut Hill, Massachusetts

United States., ugwoegbu@ab.edu

${ }^{63}$ Ibid. 172.

This publication is licensed under Creative Commons Attribution CC BY. 